\title{
Autoimmune serum factors in active and inactive lymphogranuloma venereum
}

\author{
C. E. SONCK, J. A. RÄSÄNEN, K. K. MUSTAKALLIO, AND A. LASSUS \\ From the Departments of Dermatology and Venereology, University Central Hospital, Turku and Helsinki, and the \\ Municipal Bacteriological Laboratory, Aurora Hospital, Helsinki, Finland
}

Lymphogranuloma venereum, caused by a member of the Chlamydia group of micro-organisms, in its early stages involves mainly the inguinal and iliac lymph nodes. After spreading via the lymphatics to the perirectal tissue, the disease may become chronic and cause severe suppurative destruction and stenosis.

In two other papers (Lassus, Mustakallio, and Wager, 1970; Lassus, Sonck, Wager, and Mustakallio, 1973), we have shown that both early (untreated active) and late (treated inactive) cases of lymphogranuloma venereum exhibit high levels of serum immunoglobulins, especially of the IgA and IgG classes. We also found that, in early untreated cases, there was a high incidence of autoimmune serum factors (cryoglobulins and rheumatoid factors) (Lassus and others, 1970). In this paper we compare the incidence of autoimmune serum factors in sera from early untreated and old treated cases of lymphogranuloma venereum.

\section{Material and methods}

The series comprises thirteen young men (mean age 27 years) with early untreated lymphogranuloma venereum and 38 women and four men (mean age 63 years) examined and treated by one of us (C.E.S.) from 1936 to 1951.

Of the 42 patients in the second group, 22 had severe intestinal involvement at the first examination, nine had only a mild proctitis, and eleven had no intestinal involvement. All were treated with long courses of sulphonamides. When they were re-examined for the present study none had clinical symptoms or signs of active disease, but 36 still had a positive Frei-test. The six patients with a negative Frei-test had all been Frei-positive when initially examined. All of the thirteen patients with early untreated disease were Frei-positive.

The sera of all the patients were examined for rheumatoid factor activity by the Waaler-Rose and latex-fixation tests, for cryoglobulins, antinuclear factors, and cold agglutinins, for serum anticomplementary activity by the Kolmer complement-fixation test, and finally by a direct Coombs test. The serological methods used have already been described in detail (Johansson, 1971).

Received for publication June 19, 1972

\section{Results}

These are presented in the Table. One of the patients with early untreated infection had rheumatoid factor in the serum as shown by positive Waaler-Rose and latex-fixation tests. No evidence of any rheumatic disease could be found. In six other early cases, cryoglobulins were demonstrated. Altogether seven (54 per cent.) of the thirteen early untreated cases showed either cryoglobulins or rheumatoid factor activity in the serum, but none exhibited any of the other serological abnormalities searched for.

TABLE Incidence of autoimmune serum factor in sera of 55 patients with lymphogranuloma venereum

\begin{tabular}{|c|c|c|}
\hline Group & Early untreated & Old treated \\
\hline Total no. tested & 13 & 42 \\
\hline Rheumatoid factor activity & 1 & 9 \\
\hline Cryoglobulins & 6 & 6 \\
\hline Antinuclear factors & - & 3 \\
\hline Coombs test positive & - & 3 \\
\hline Anticomplementary activity & - & 1 \\
\hline Cold agglutinins & - & - \\
\hline $\begin{array}{l}\text { At least one abnormality } \\
\text { present No. } \\
\text { Per cent. }\end{array}$ & $\begin{array}{r}7 \\
54\end{array}$ & $\begin{array}{l}13 \\
31\end{array}$ \\
\hline
\end{tabular}

Thirteen ( 31 per cent.) of the 42 late treated cases had one or more serological abnormality. Rheumatoid factor activity was found in nine cases ( 21 per cent.), the Waaler-Rose test being positive in four and the latex-fixation test in all nine. One of these nine patients had rheumatoid arthritis. Cryoglobulins were found in six (14 per cent.), antinuclear factors at low titres in three ( 7 per cent.), a positive Coombs test in three ( 7 per cent.), and serum anticomplementary activity in one ( 2 per cent.). None had cold agglutinins. The presence of autoimmune serum factors did not seem to correlate with the severity of the intestinal involvement or the persistence of Frei-positivity. 


\section{Comment}

Many infectious diseases are known to provoke the development of autoimmune serum factors. For example, patients with syphilis and leprosy frequently show cryoglobulins and rheumatoid factor in the serum (Mustakallio, Lassus, and Wager, 1967; Bonomo and Damacco, 1968; Matthews and Trautman, 1965). In syphilitic patients this is especially the case in the florid secondary stage (Lassus, 1969), but the incidence is low in late adequately treated cases (Lassus-unpublished data).

It was not surprising that many of the patients with early untreated disease had cryoglobulins in the serum, but it was not expected that one-third of the patients with late treated disease would have autoimmune serum factors. This, together with our earlier finding that over one-third of patients with late treated lymphogranuloma venereum showed raised levels of serum immunoglobulins, especially of the IgA and IgG classes (Lassus and others, in press), suggests that in some cases of lymphogranuloma venereum an immunological stimulus continues in spite of treatment and healing of the clinical lesions.

\section{Summary}

Sera from thirteen patients with recent untreated and 42 patients with late treated lymphogranuloma venereum were examined for the presence of autoimmune serum factors. Seven of the early untreated cases (54 per cent.) had either cryoglobulins or rheumatoid factor activity in the serum. Thirteen of the 42 late cases ( 31 per cent.) had one or several of the serological abnormalities searched for: rheu- matoid factor activity (9), cryoglobulins (6), antinuclear factors (3), positive Coombs test (3), and anticomplementary serum activity (1).

\section{References}

Bonomo, L., and Dammacco, F. (1968) In 'Proc. Int. Symp. on Gammapathies, Infections, Cancer and Immunity, 1967', ed. V. Chini, L. Bonomo, and C. Sirtori, p. 12. Carlo Erba Foundation, Milan

Johansson, E. A. (1971) Acta derm.-venereol. (Stockh.), 51, Suppl. 65

Lassus, A. (1969) Int. Arch. Allergy, 36, 515

-, Mustakallio, K. K., and Wager, O. (1970) Ann. clin. Res., 2, 51

—, SONCK, C. E., WAGER, O., and Mustakallio, K. K. (In press) 'Venereal Diseases'. Thomas, Springfield, Ill.

Matrhews, L. J., and Trautman, J. R. (1965) Lancet, 2, 915

Mustakallio, K. K., Lassus, A., and Wager, O. (1967) Int. Arch. Allergy, 31, 417

Facteurs autoimmuns dans la lymphogranulomatose vénérienne active et inactive

SOMMAIRE

Les sérums de treize malades atteints de lymphogranulomatose vénérienne non traitée et de 42 malades anciennement traités furent examinés pour la présence de facteurs sériques autoimmuns. Sept des cas récents non traités (54 pour cent) avaient dans leur sérum soit des cryoglobulines, soit le facteur rhumatismal. Treize des 42 cas anciens ( 31 pour cent) présentaient une ou plusieurs des anomalies suivantes parmi celles qui furent recherchées: facteur d'activité rhumatoìde (9), cryoglobulines (6), facteurs antinucléaires (3), test de Coombs positif (3), et activité anticomplémentaire du sérum (1). 